\title{
THE PROFILE OF JUNIOR HIGH SCHOOL STUDENTS ABOUT PISA PROBLEM SOLVING BASED ON PERSONALITY TYPE
}

\author{
Siti Mar'atus Solichah \\ Mathematics Education, Faculty of Mathematics and Natural Sciences, Universitas Negeri Surabaya \\ e-mail: sitisolichah@mhs.unesa.ac.id \\ Raden Sulaiman \\ Mathematics Education, Faculty of Mathematics and Natural Sciences, Universitas Negeri Surabaya \\ e-mail: radensulaiman@unesa.ac.id
}

\begin{abstract}
One of the goals of learning mathematics is students can solve the problems. PISA problems can be used to bring up the problem solving activities. Keirsey's personality type is chosen because it offers possibility on differences in each personality type. It is based on the characteristics in taking and processing information, making decisions, and patterning the implementation of their tasks. The aim of this research is describing the profile of junior high school students about PISA problem solving based on personality type. This research is a qualitative descriptive research using test and interview methods. The subjects consist of four students, which are guardian, artisan, rational, and idealist. The results showed that on the understanding the problem stage, all students read the questions and were capable in identifying the information in the question. Then represented what is known and unknown. At the devising a plan stage, the four subjects were able to link the information that was known with prior knowledge to make a plan. At the carrying out the plan stage, the four subjects used the appropriate knowledge to implement the settlement plan that has been made. At the looking back stage, all the students examine their solutions.
\end{abstract}

Keywords: problem solving, PISA questions, personality type

\section{INTRODUCTION}

Education is an activity to improve and develop capabilities in various aspects including knowledge and skills. Education in Indonesian teaches several scientific disciplines that can improve and develop students' abilities, one of them is mathematics. Although taught starting from the basic level of education, mathematics is still considered a difficult subject for students.

Based on the Ministry of Education and Culture report in several newspapers stated that there was a decline in the average National Examination (UN) of junior and senior high school level academic year 2017/2018 on mathematics subjects. As in the May 8, 2018 edition of Tribunnews.com, it was explained by the Head of Research and Development Totok Suprayitno that vocational high school mathematics national examination dropped 3 points, while the senior high school 4.6 points. In line with that statement, in TEMPO.CO May 252018 edition, Muhadjir Effendy stated that there was a decline in scores at the junior high school level due to the problem of HOTS (High Order Thinking Skills). Meanwhile, based on the Organization for Economic Co-operation and Development (OECD) report on the PISA results, international studies every three years about reading, mathematics, science, problem solving, and financial literacy for students aged 15 years, in 2012 stated that mathematics scores of Indonesian students was ranked $64^{\text {th }}$ out of 65 countries. Whereas in 2015 the mathematics scores of Indonesian students was ranked $63^{\text {th }}$ out of 70 countries.

Based on the results of the National Examination and PISA, a better mathematical ability is needed in solving problems. Shadiq (2004) states that problem solving will be the thing that really determines the success of mathematics education, so integration of problem solving during the learning process takes place should be a necessity. NCTM (2000) also states that problem solving is one of the standard processes in learning mathematics besides communication, reasoning and proof, representation and connections. Siswono (2008) defines problem solving as a process or effort of an individual to respond or overcome obstacles or constraints when an answer or method of answer is not yet clear.

Wardhani \& Rumiati (2011) stated that PISA questions demand and measure reasoning and problem solving abilities, although not all questions. Space and shape content is suitable for knowing student problem solving. 
Space and shape content is related to the field of geometry (OECD, 2016). Walle (2001) states that there are five reasons why geometry needs to be studied. One of them is exploration in geometry can help students to develop problem solving abilities. In line with Walle, Murtafi'ah \& Masfingatin (2015) states that from a mathematical point of view, geometry provides approaches to problem solving, for example images, diagrams, coordinate systems, vectors, and transformations.

To be able to solve the problem properly, the right stages are needed. Polya through his book How to Solve It (1973) provides four stages of problem solving called Polya heuristic stages. The four stages consist of: (1) understanding the problem; (2) devising plan; (3) carrying out the plan; and (4) looking back.

Based on Piaget's cognitive development theory, students at the junior high school level, aged 11 years and above, have entered the formal operational stage. At this stage, students can develop their ability to solve problems in a better way, can provide reasons in decision making, and can see abstract relationships (Nursalim, et al, 2007).

Research conducted by Dewiyani (2010) states that the Keirsey personality type known as Keirsey Temperament Sorter (KTS) can influence an individual's thinking process in problem solving. Things that are done or decided in solving problems by students one another are different due to differences in personality. In his book Please Understand Me II, Keirsey (1998) classifies personality into four personality types namely guardian (sensing \& judging), artisan (sensing \& perceiving), rational (intuitive \& thinking) and idealist (intuitive \& feeling). Keirsey's personality type is based on the characteristics of each individual in taking and processing information, making decisions, and patterning the implementation of their tasks.

The problems raised in this research about "How students' problem solving with their personality type in solving PISA problems". And the aim of the research is describing the profile of junior high school students about PISA problem solving based on personality type.

\section{METHODS}

The research is a qualitative descriptive research that was conducted in two class at SMPN 4 Sidoarjo, exactly at grade eight academic year 2018/2019. Four students from class VIII-A and VIII-H were chosen to be the research subjects.

The procedure of research are described in the Figure 1, from beginning until getting the students' problem solving results.

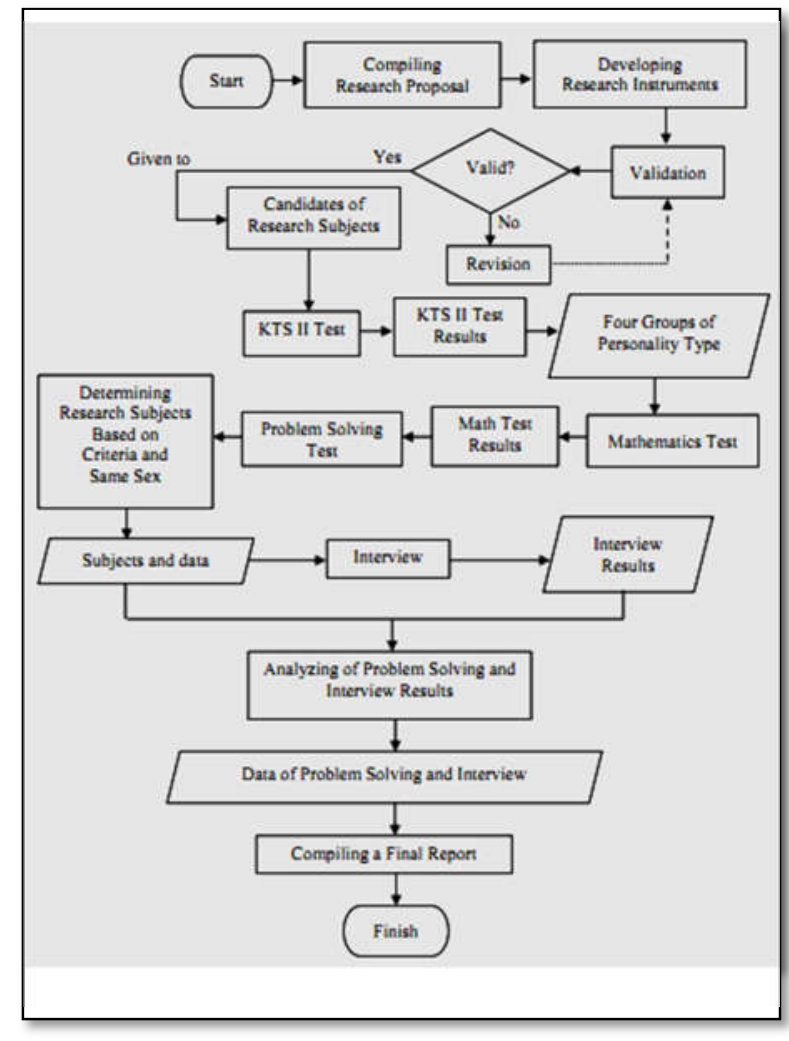

Figure 1. Procedure of Research

This research were used four instruments:

1. Keirsey Temperament Sorter (KTS) II Test that was checked its validity and reliability. This test was adapted from Keirsey (1998) with the title "Please Understand Me II'.

2. Mathematics Test with essay type. This test is validated by two mathematics lecturer and a mathematics teacher of SMPN 4 Sidoarjo.

3. Problem Solving Test that contains a PISA question of space and shape content with the title "Continent Area". This test is validated by two mathematics lecturer and a mathematics teacher of SMPN 4 Sidoarjo.

4. Interview guide that was consulted by mathematics lecturer.

This research was done four times. For the first, the researchers gave KTS II Test to students VIII-A and VIIIH. Second, the researchers gave Mathematics Test to measure students' mathematical abilities. Third, data were collected with Problem Solving Test to uncover the students' problem solving. Fourth or last, the interview process to verify and uncover the students' problem solving.

The analysis of scoring the KTS II Test with scoring orientation. There are 70 questions to classify, it was clasified by category of sensing \& judging for guardian, sensing \& perceiving for artisan, intuitive \& thinking for 
rational and intuitive \& feeling for idealist. After that, the analyze of Mathematics Test. Students with score greater than or equal to 75 are chosen to be candidates of research subject. The analysis for Problem Solving Test based on indicators with Polya'stages. Then four research subjects were selected with correct answer and fulfilling many indicators. They are one guardian's students, artisan's students, rational's students and idealist's students.

The analysis of data of research subjects included Problem Solving Test and Interview were analyzed based on indicators that refer to Polya's stages (understanding the problem, devising a plan, carrying out the plan, and looking back).

\section{RESULTS AND DISCUSSIONS}

First day at SMPN 4 Sidoarjo, the researchers gave KTS II Test to 73 students in class VIII A and VIII H. Based on the students' result, students grouped into five categories.

Table 1. Distribution of Students' Personality Type

\begin{tabular}{|c|c|c|c|c|c|}
\hline \multicolumn{5}{|c|}{ Personality Type } & \multirow{2}{*}{ Total } \\
\cline { 1 - 4 } GU & AR & RA & ID & Negligible & \\
\hline 32 & 14 & 10 & 10 & 7 & 73 \\
\hline
\end{tabular}

From Table 1, there are 32 students with guardian type, 14 students with artisan type, 10 students with rational type and 10 students with idealist type. Based on Mathematics Test scores, Problem Solving Test and teacher recommendation, four research subjects were obtained as in the Table 2.

Table 2. Research Subjects

\begin{tabular}{|c|c|c|c|c|c|}
\hline No & Name & Code & Gender & $\begin{array}{c}\text { Math } \\
\text { Test }\end{array}$ & $\begin{array}{c}\text { Personality } \\
\text { Type }\end{array}$ \\
\hline 1 & ASP & GU & F & 85 & Guardian \\
\hline 2 & AKT & AR & F & 84 & Artisan \\
\hline 3 & NZA & RA & F & 83 & Rational \\
\hline 4 & ANY & ID & F & 81 & Idealist \\
\hline
\end{tabular}

Notes:

$\mathrm{GU}=$ students with guardian type

$\mathrm{AR}=$ students with artisan type

RA = students with rational type

ID = students with idealist type

The students' answer of Problem Solving Test is encoded by researchers and presented in Table 3.

Table 3. The Code of Problem Solving Test Results

\begin{tabular}{|c|c|}
\hline Code & Explanation \\
\hline \multirow{3}{*}{ Jxxxxx } & $\begin{array}{c}\text { J in the first states as subject's answer } \\
\text { xx in the second and third states as } \\
\text { students' personality type } \\
\mathrm{x} \text { in the fourth states as question number } \\
\mathrm{xx} \text { in the fifth and sixth states as order of } \\
\text { students' answer }\end{array}$ \\
\hline
\end{tabular}

1. Data Analysis about Students' PISA Problem Solving a. Data Analysis of GU
The description of GU is presented in the following figure and table.

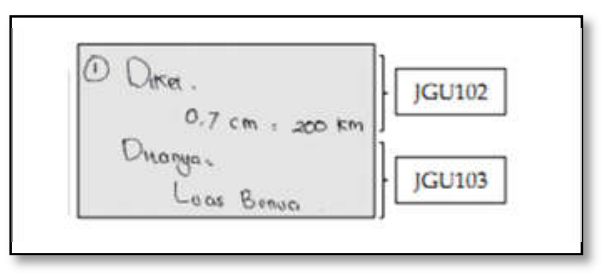

Figure 2. GU's Answer

Table 4. The Description of GU's Answer

\begin{tabular}{|c|c|c|}
\hline $\begin{array}{l}\text { Polya's } \\
\text { Stages }\end{array}$ & Indicators & Description \\
\hline \multirow[t]{4}{*}{$\begin{array}{l}\text { Understanding } \\
\text { the Problem }\end{array}$} & $\begin{array}{l}\text { Read PISA } \\
\text { question }\end{array}$ & $\begin{array}{l}\text { GU reads the problem } \\
5 \text { times to understand } \\
\text { the problem. }\end{array}$ \\
\hline & $\begin{array}{l}\text { Identify the } \\
\text { data, } \\
\text { condition, } \\
\text { and } \\
\text { unknown. }\end{array}$ & $\begin{array}{l}\text { GU identify all the } \\
\text { data (map and scale), } \\
\text { unknown (the area of } \\
\text { map), and condition. }\end{array}$ \\
\hline & $\begin{array}{l}\text { Identify } \\
\text { adequacy of } \\
\text { information }\end{array}$ & $\begin{array}{l}\text { Doubtfully, GU states } \\
\text { that all information is } \\
\text { sufficient to be used } \\
\text { to solve the problem. }\end{array}$ \\
\hline & $\begin{array}{l}\text { Represent } \\
\text { the data and } \\
\text { unknown }\end{array}$ & $\begin{array}{l}\text { GU represents data in } \\
\text { symbol (JGU102) and } \\
\text { unknown in verbal } \\
(\mathrm{JGU} 103) .\end{array}$ \\
\hline $\begin{array}{l}\text { Devising a } \\
\text { Plan }\end{array}$ & $\begin{array}{l}\text { Associate } \\
\text { the data with } \\
\text { prior } \\
\text { knowledge }\end{array}$ & $\begin{array}{l}\text { GU closes the area of } \\
\text { Antarctica with some } \\
\text { two dimentional } \\
\text { figure, such as: } \\
\text { triangle, trapezoid and } \\
\text { rectangle. After that, } \\
\text { GU moves the area of } \\
\text { Antarctica which is } \\
\text { not covered to two } \\
\text { dimentional figure } \\
\text { that has been made } \\
\text { and still has an empty } \\
\text { area. Then, GU } \\
\text { determines the size of } \\
\text { length, width, etc and } \\
\text { changes into real size. } \\
\text { GU determines each } \\
\text { area of two } \\
\text { dimentional figure } \\
\text { and adds them. }\end{array}$ \\
\hline $\begin{array}{l}\text { Carrying Out } \\
\text { the Plan }\end{array}$ & $\begin{array}{l}\text { Use } \\
\text { appropriate }\end{array}$ & $\begin{array}{l}\text { GU uses the } \\
\text { appropriate }\end{array}$ \\
\hline
\end{tabular}




\begin{tabular}{|l|l|l|}
\hline \multicolumn{1}{|c|}{$\begin{array}{c}\text { Polya's } \\
\text { Stages }\end{array}$} & Indicators & \multicolumn{1}{c|}{ Description } \\
\hline \multirow{1}{*}{} & $\begin{array}{l}\text { knowledge } \\
\text { to } \\
\text { implement } \\
\text { the plan }\end{array}$ & $\begin{array}{l}\text { knowledge such as: } \\
\text { the formula to } \\
\text { determine the area of } \\
\text { two dimentional } \\
\text { figure, number } \\
\text { counting operation. }\end{array}$ \\
\cline { 2 - 4 } & $\begin{array}{l}\text { Check the } \\
\text { plan }\end{array}$ & $\begin{array}{l}\text { GU examines all the } \\
\text { steps and formula that } \\
\text { are used in solving the } \\
\text { problem. }\end{array}$ \\
\hline Looking Back & $\begin{array}{l}\text { Check all } \\
\text { the solution }\end{array}$ & $\begin{array}{l}\text { GU does not examine } \\
\text { solutions in detail, but } \\
\text { only check on } \\
\text { calculations that are } \\
\text { considered important. }\end{array}$ \\
\hline
\end{tabular}

In solving the problem, GU returns to the stage of understanding the problem after carrying out the plan. It is possible due to their own sensing. Someone with this nature relies more on the five senses and only focuses on facts when taking and processing information (Russo \& Kaynama, 2012). The sequences of stages that performed by GU is understanding the problem, devising a plan, carrying out the plan, understanding the problem, carrying out the plan, and looking back. The sequences of GU is presented in Figure 3.

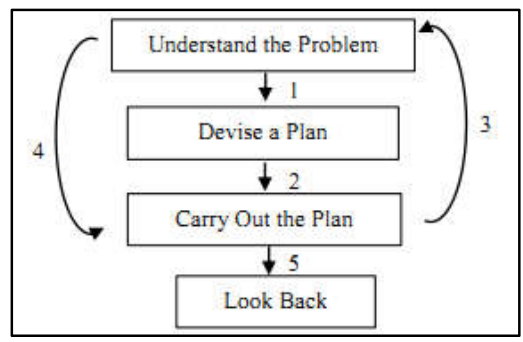

Figure 3. The Sequences of GU

b. Data Analysis of AR

The description of AR is presented in the following figure and table.

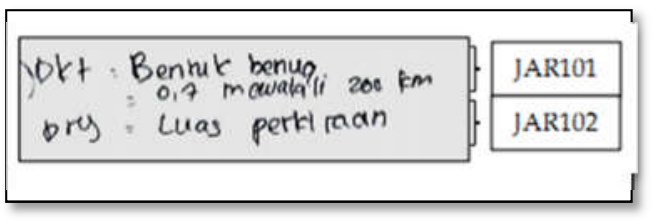

Figure 4. AR's Answer
Table 5. The Description of AR's Answer

\begin{tabular}{|c|c|c|}
\hline $\begin{array}{l}\text { Polya's } \\
\text { Stages }\end{array}$ & Indicators & Description \\
\hline \multirow[t]{4}{*}{$\begin{array}{l}\text { Understanding } \\
\text { the Problem }\end{array}$} & $\begin{array}{l}\text { Read PISA } \\
\text { question }\end{array}$ & $\begin{array}{l}\text { AR reads the problem } \\
3 \text { times to understand } \\
\text { the problem. }\end{array}$ \\
\hline & $\begin{array}{l}\text { Identify the } \\
\text { data, } \\
\text { condition, } \\
\text { and } \\
\text { unknown. }\end{array}$ & $\begin{array}{l}\text { AR identify all the } \\
\text { data (map and scale), } \\
\text { unknown (the area of } \\
\text { map), and condition. }\end{array}$ \\
\hline & $\begin{array}{l}\text { Identify } \\
\text { adequacy of } \\
\text { information }\end{array}$ & $\begin{array}{l}\text { Doubtfully, AR states } \\
\text { that all information is } \\
\text { insufficient to be used } \\
\text { to solve the problem. }\end{array}$ \\
\hline & $\begin{array}{l}\text { Represent } \\
\text { the data and } \\
\text { unknown }\end{array}$ & $\begin{array}{l}\text { AR represents data in } \\
\text { verbal \& symbol } \\
\text { (JAR101) and } \\
\text { unknown in verbal } \\
\text { (JAR102). }\end{array}$ \\
\hline $\begin{array}{l}\text { Devising a } \\
\text { Plan }\end{array}$ & $\begin{array}{l}\text { Associate } \\
\text { the data with } \\
\text { prior } \\
\text { knowledge }\end{array}$ & $\begin{array}{l}\text { AR makes two } \\
\text { dimentional figure. } \\
\text { AR transforms the } \\
\text { area of Antarctica into } \\
\text { triangle and rectangle. } \\
\text { After that, AR moves } \\
\text { the area of Antarctica } \\
\text { which is not covered } \\
\text { to two dimentional } \\
\text { figure that has been } \\
\text { made and still has an } \\
\text { empty area. Then, AR } \\
\text { determines the size of } \\
\text { length, width, etc and } \\
\text { changes into real size. } \\
\text { AR determines each } \\
\text { area of two } \\
\text { dimentional figure } \\
\text { and adds them. }\end{array}$ \\
\hline \multirow[t]{2}{*}{$\begin{array}{l}\text { Carrying Out } \\
\text { the Plan }\end{array}$} & $\begin{array}{l}\text { Use } \\
\text { appropriate } \\
\text { knowledge } \\
\text { to } \\
\text { implement } \\
\text { the plan }\end{array}$ & $\begin{array}{l}\text { AR uses the } \\
\text { appropriate } \\
\text { knowledge such as: } \\
\text { the formula to } \\
\text { determine the area of } \\
\text { two dimentional } \\
\text { figure, number } \\
\text { counting operation. }\end{array}$ \\
\hline & $\begin{array}{l}\text { Check the } \\
\text { plan }\end{array}$ & $\begin{array}{l}\text { AR does not examine } \\
\text { all the steps that are } \\
\text { used in solving the } \\
\text { problem. }\end{array}$ \\
\hline
\end{tabular}


THE PROFILE OF STUDENTS' PROBLEM...

\begin{tabular}{|c|l|l|}
\hline \multicolumn{1}{|c|}{$\begin{array}{c}\text { Polya's } \\
\text { Stages }\end{array}$} & Indicators & \multicolumn{1}{c|}{ Description } \\
\hline Looking Back & $\begin{array}{l}\text { Check all } \\
\text { the solution }\end{array}$ & $\begin{array}{l}\text { AR check the } \\
\text { suitability of the } \\
\text { answer to what the } \\
\text { questions are asked } \\
\text { for. }\end{array}$ \\
\hline
\end{tabular}

In solving the problem, AR returns to the stage of understanding the problem after AR carrying out the plan. It is possible due to their own sensing. Someone with this nature relies more on the five senses and only focuses on facts when taking and processing information (Russo \& Kaynama, 2012). The sequences of stages that performed by $\mathrm{AR}$ is understanding the problem, devising a plan, carrying out the plan, understanding the problem, carrying out the plan, and looking back. The sequences of AR is presented in Figure 5.

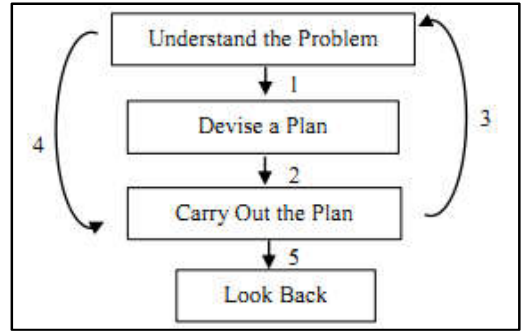

Figure 5. The Sequences of AR

c. Data Analysis of RA

The description RA is presented in the following figure and table.

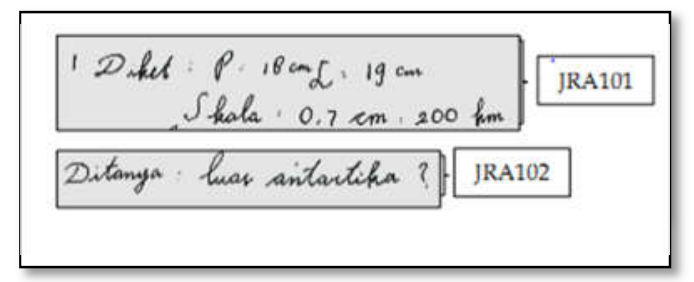

Figure 6. RA's Answer

Table 6. The Description of RA's Answer

\begin{tabular}{|l|l|l|}
\hline \multicolumn{1}{|c|}{$\begin{array}{c}\text { Polya's } \\
\text { Stages }\end{array}$} & Indicators & \multicolumn{1}{c|}{ Description } \\
\hline $\begin{array}{l}\text { Understanding } \\
\text { the Problem }\end{array}$ & $\begin{array}{l}\text { Read PISA } \\
\text { question }\end{array}$ & $\begin{array}{l}\text { RA reads the problem } \\
\text { 2 times to understand } \\
\text { the problem. }\end{array}$ \\
\cline { 2 - 3 } & $\begin{array}{l}\text { Identify the } \\
\text { data, } \\
\text { condition, } \\
\text { and } \\
\text { unknown. }\end{array}$ & $\begin{array}{l}\text { RA identify all the } \\
\text { data (map and scale), } \\
\text { unknown (the area of } \\
\text { map), and condition. }\end{array}$ \\
\hline
\end{tabular}

\begin{tabular}{|c|c|c|}
\hline Polya's & Indicators & Description \\
\hline & $\begin{array}{l}\text { Identify } \\
\text { adequacy of } \\
\text { information }\end{array}$ & $\begin{array}{l}\text { RA states that all } \\
\text { information is } \\
\text { sufficient to be used } \\
\text { to solve the problem. }\end{array}$ \\
\hline & $\begin{array}{l}\text { Represent } \\
\text { the data and } \\
\text { unknown }\end{array}$ & $\begin{array}{l}\text { RA represenst data in } \\
\text { verbal \& symbol } \\
\text { (JRA101) and } \\
\text { unknown in verbal } \\
\text { (JRA102). }\end{array}$ \\
\hline $\begin{array}{l}\text { Devising a } \\
\text { Plan }\end{array}$ & $\begin{array}{l}\text { Associate } \\
\text { the data with } \\
\text { prior } \\
\text { knowledge }\end{array}$ & $\begin{array}{l}\text { RA makes a rectangle } \\
\text { outside the area of } \\
\text { Antarctica. After that, } \\
\text { RA makes some two } \\
\text { dimentional figure in } \\
\text { empty part of } \\
\text { rectangle. Then, RA } \\
\text { determines the size of } \\
\text { length, width, etc and } \\
\text { changes into real size. } \\
\text { RA determines each } \\
\text { area of two } \\
\text { dimentional figure. At } \\
\text { the last, RA reduces } \\
\text { the area of rectangle } \\
\text { with the area of some } \\
\text { two dimentional } \\
\text { figure inside. }\end{array}$ \\
\hline \multirow[t]{2}{*}{$\begin{array}{l}\text { Carrying Out } \\
\text { the Plan }\end{array}$} & $\begin{array}{l}\text { Use } \\
\text { appropriate } \\
\text { knowledge } \\
\text { to } \\
\text { implement } \\
\text { the plan }\end{array}$ & $\begin{array}{l}\text { AR uses the } \\
\text { appropriate } \\
\text { knowledge such as: } \\
\text { the formula to } \\
\text { determine the area of } \\
\text { two dimentional } \\
\text { figure, number } \\
\text { counting operation. }\end{array}$ \\
\hline & $\begin{array}{l}\text { Check the } \\
\text { plan }\end{array}$ & $\begin{array}{l}\text { RA examines all the } \\
\text { steps and formula that } \\
\text { are used in solving the } \\
\text { problem. }\end{array}$ \\
\hline Looking Back & $\begin{array}{l}\text { Check all } \\
\text { the solution }\end{array}$ & $\begin{array}{l}\text { RA does not examine } \\
\text { solutions in detail, but } \\
\text { only check on } \\
\text { calculations that are } \\
\text { considered important. }\end{array}$ \\
\hline
\end{tabular}

In solving the problem, RA resolves the problem so confidently and sequentially. It is possible due to their own intuitive. Someone with this nature when taking and processing information tends to see patterns and their relevance (Russo \& Kaynama, 2012). In addition, it is 
possible due to their own thinking. Someone with this nature tends to decide something logically and according to the provisions given (Russo \& Kaynama, 2012). The sequences of stages that performed by RA is understanding the problem, devising a plan, carrying out the plan and looking back. The sequences of RA is presented in Figure 7.

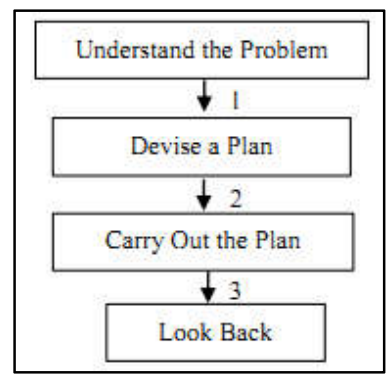

Figure 7. The Sequences of RA

d. Data Analysis of ID

The description of ID is presented in the following figure and table.

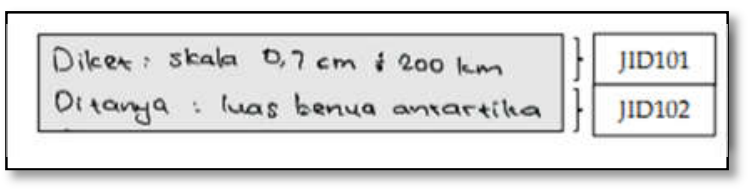

Figure 8. ID's Answer

Table 7. The Description of ID's Answer

\begin{tabular}{|l|l|l|}
\hline \multicolumn{1}{|c|}{$\begin{array}{c}\text { Polya's } \\
\text { Stages }\end{array}$} & Indicators \\
the Problem & $\begin{array}{l}\text { Read PISA } \\
\text { question }\end{array}$ & $\begin{array}{l}\text { ID reads the problem } \\
\text { 2 times to understand } \\
\text { the problem. }\end{array}$ \\
\cline { 2 - 4 } & $\begin{array}{l}\text { Identify the } \\
\text { data, } \\
\text { condition, } \\
\text { and } \\
\text { unknown. }\end{array}$ & $\begin{array}{l}\text { ID identify all the } \\
\text { data (map and scale), } \\
\text { unknown (the area of } \\
\text { map), and condition. }\end{array}$ \\
\cline { 2 - 3 } & $\begin{array}{l}\text { Identify } \\
\text { adequacy of } \\
\text { information }\end{array}$ & $\begin{array}{l}\text { ID states that all } \\
\text { information is } \\
\text { insufficient to be used } \\
\text { to solve the problem. }\end{array}$ \\
\cline { 2 - 4 } & $\begin{array}{l}\text { Represent } \\
\text { the data and } \\
\text { unknown }\end{array}$ & $\begin{array}{l}\text { ID represents data in } \\
\text { verbal \& symbol } \\
\text { (JID101) and } \\
\text { unknown in verbal } \\
\text { (JID102). }\end{array}$ \\
\hline $\begin{array}{l}\text { Devising a } \\
\text { Plan }\end{array}$ & $\begin{array}{l}\text { Associate } \\
\text { the data with } \\
\text { prior } \\
\text { knowledge }\end{array}$ & $\begin{array}{l}\text { ID transforms the area } \\
\text { of Antarctica into a } \\
\text { rectangle. After that, } \\
\text { ID moves the area of }\end{array}$ \\
\hline
\end{tabular}

\begin{tabular}{|c|c|c|}
\hline $\begin{array}{l}\text { Polya's } \\
\text { Stages }\end{array}$ & Indicators & Description \\
\hline & & $\begin{array}{l}\text { Antarctica which is } \\
\text { not covered by } \\
\text { rectangle that has } \\
\text { been made and still } \\
\text { has an empty area. } \\
\text { Then, ID determines } \\
\text { the size of length, } \\
\text { width, etc and } \\
\text { changes into real size. } \\
\text { And the last, ID } \\
\text { determines the area of } \\
\text { rectangle. }\end{array}$ \\
\hline \multirow[t]{2}{*}{$\begin{array}{l}\text { Carrying Out } \\
\text { the Plan }\end{array}$} & $\begin{array}{l}\text { Use } \\
\text { appropriate } \\
\text { knowledge } \\
\text { to } \\
\text { implement } \\
\text { the plan }\end{array}$ & $\begin{array}{l}\text { ID uses the } \\
\text { appropriate } \\
\text { knowledge such as: } \\
\text { the formula to } \\
\text { determine the area of } \\
\text { rectangle, number } \\
\text { counting operation. }\end{array}$ \\
\hline & $\begin{array}{l}\text { Check the } \\
\text { plan }\end{array}$ & $\begin{array}{l}\text { ID does not examine } \\
\text { all the steps that are } \\
\text { used in solving the } \\
\text { problem. }\end{array}$ \\
\hline Looking Back & $\begin{array}{l}\text { Check all } \\
\text { the solution }\end{array}$ & $\begin{array}{l}\text { ID examines solutions } \\
\text { in detail and check all } \\
\text { the calculations that } \\
\text { were used. }\end{array}$ \\
\hline
\end{tabular}

In solving the problem, ID repeats to re-plan because there is an error in the first plan. It is possible due to their own feeling. Someone with this nature tends to decide something subjectively and adapts to the situation (Russo \& Kaynama, 2012). The sequences of stages that performed by ID is understanding the problem, devising a plan, carrying out the plan, devising a plan, carrying out the plan, and looking back. The sequences of ID is presented in Figure 9.

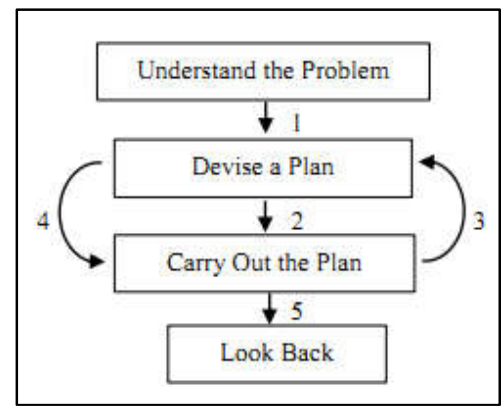

Figure 9. The Sequences of ID

2. Discussions 
a. The researchers do not pay attention to the strong or weak personality type of each research subjects.

b. The researches lack of information in identifying the strategies that used by students in solving problem at the step of devising a plan.

\section{CLOSURE}

\section{Conclusions}

Based on the description and analysis results, it can be concluded that all of students with their personality type (guardian, artisan, rational, and idealist) solve the problem by their way and use all of Polya's stages. All the students satisfy all the indicators that has been made by the researchers. Each personality type shows their characteristics to solve the problem, especially sequences in solving the problem. Guardian, artisan and idealist students solve the problem not sequentially and back in the previous stage. But rational student solve the problem systematically.

\section{Suggestions}

1. For the next research, it is need to control the weaknesses that have been done by researches, such as: pay attention to strength or weakness of the personality type of the research subject.

2. Uncover deeper about identifying strategies used by students in solving problems at the step of devising a plan.

3. Using subjects who have different levels of mathematical abilities, so that differences in problem solving for PISA problem can be seen in guardian, artisan, rational and idealist students who have low, medium and high mathematical abilities.

\section{REFERENCES}

Antara. 25 Mei 2018. TEMPO.CO: Mendikbud Jelaskan Kenapa Nilai Rata-Rata UN SMP 2018 Turun, (Online),

(https://nasional.tempo.co/read/1092395/mendikbudjelaskan-kenapa-nilai-rata-rata-hasil-un-smp-2018turun, accessed at 10 November 2018).

Dewiyani, S. M. J., 2010. Profil Proses Berpikir Mahasiswa Ditinjau Dari Tipe Kepribadian dan Gender. Disertasi tidak diterbitkan. Surabaya: PPs Universitas Negeri Surabaya.

Indonesia PISA Center Mathematics website for CBAM, (Online), (http://www.indonesiapisacenter.com/, accessed at 25 November 2018)

Keirsey, David. 1998. Please Understand Me II Temperament, Character, and Intelligence. California: Promotheus Nemesis Book Company.
Murtafi'ah, W \& Masfingatin, T. 2015. "Proses Berpikir Mahasiswa dengan Kemampuan Spatial Intelligent Tinggi dalam Memecahkan Masalah Geometri”. Kadikma, Vol 6 (1), hal: 133-148.

NCTM. 2000. Principles and Standards for School Mathematics. United States of America: The National Council of Teachers of Mathematics, Inc.

Nursalim, Mochamad, dkk. 2007. Psikologi Pendidikan. Surabaya: Unesa University Press.

OECD. 2006. PISA Released Items-Mathematics,

(Online), (http://www.oecd.org/pisa/38709418.pdf, accessed at 1 December 2018).

OECD. 2014. PISA 2012 Result in Focus: What 15-YearsOld Know and what They Can Do with They Know. Paris: PISA OECD Publishing.

OECD. 2016. PISA 2015 Assesment and Analytical Framework: Science, Reading, Mathematic and Financial Literacy. Paris: PISA OECD Publishing.

Polya, George. 1973. How to Solve It: A New Aspect of Mathematical Method. New Jearsey: Princeton University Press.

Russo, C. J. and Kaynama, S. 2012. "The Impact of Personality Type and Gender on Student' Performance in a Business Capstone Course". Academy of Educational Leadership Journal, Vol. 16 (1).

Shadiq, Fajar. 2004. Pemecahan Masalah, Penalaran dan Komunikasi. Makalah disajikan dalam Diklat Instruktur/Pengembang Matematika SMA Jenjang Dasar, Yogyakarta, 6-19 Juli.

Siswono, T. Y. E. 2008. Model Pembelajaran Matematika Berbasis Pengajuan dan Pemecahan Masalah Untuk Meningkatkan Kemampuan Berpikir Kreatif. Surabaya: Unesa University Press.

Tribunnews.com. 8 Mei 2018. Kemendikbud: Secara Umum Terjadi Penurunan Rata-Rata Nilai UN SMU dan SMK 2018, (Online), (http://www.tribunnews.com/nasional/2018/05/08/ke mendikbud-secara-umum-terjadi-penurunan-rata-ratanilai-un-smu-dan-smk-2018, accessed at 12 November 2018).

Walle, J.A. 2001. Geometric Thinking and Geometric Concepts: In Elementary and Middle School Mathematics: Teaching Developmentally, 4th ed. Boston: Allyn and Bacon.

Wardhani, S \& Rumiati. 2011. Instrumen Penilaian Hasil Belajar Matematika SMP: Belajar dari PISA dan TIMSS. Yogyakarta: Pusat Pengembangan dan Pemberdayaan Pendidikan dan Tenaga Kependidikan (PPPPTK) Matematika. 